\title{
Sustainability of Steel Office Buildings ${ }^{\dagger}$
}

\author{
Filip Broniewicz * and Miroslaw Broniewicz \\ Faculty of Civil Engineering and Environmental Sciences, Bialystok University of Technology, \\ Wiejska 45E, 15-351 Białystok, Poland; m.broniewicz@pb.edu.pl \\ * Correspondence: f.broniewicz@doktoranci.pb.edu.pl \\ † Presented at the 9th Innovations-Sustainability-Modernity-Openness Conference (ISMO'20), Bialystok, \\ Poland, 20-21 May 2020.
}

Published: 16 July 2020

\begin{abstract}
Sustainable construction is an important part of sustainable development because of its contribution to the economy as well as the environmental and social impact of buildings on our lives. Steel is one of the most basic materials, both in structures and for finishes. It enables efficiency, durability, and recyclability, especially for office buildings. All these features of steel show its sustainable potential. Consumers are becoming increasingly concerned about the environment. They need to be able to make informed decisions about the impact of their actions. This publication aims to sets out key themes for the design and construction of sustainable buildings. Recent examples of office buildings are presented to illustrate how this is being achieved in steel construction.
\end{abstract}

Keywords: sustainable construction; steel buildings; design for deconstruction

\section{Introduction}

According to the Polish Environmental Protection Law, when manufacturing products, it is necessary to minimise the consumption of substances and energy, to use substances and technical solutions with a minimum negative impact on the environment during the period of operation of the product and after it, and to use substances and technical solutions which make it possible to repair the product, disassemble it to separate used elements and apply parts of the product in another product or use them for other purposes. All these recommendations are met with steel, which is the most processed structural material. Sustainable building design is based on methods and processes that are compatible with nature and do not cause harmful effects on the natural and social environment [1]. Sustainable building design is the erection of buildings that meet the uppermost environmental standards, achieving the highest ratings in multi-criteria building assessment systems. It is a process which, in conventional design, introduces principles and priorities related to the environmental impact of a building at every stage of its life. It ensures the identification of stages with a particular environmental impact throughout the product life cycle and allows to make a comparative analysis of the environmental impact of different products, materials and building structures performing the same functions [2].

\section{Environmental Impact of Steel Buildings}

Steel office buildings are characterized by the use of steel as the main construction material. Steel is also the main element in building partitions (walls, roofing), fasteners, substructures, and concrete reinforcement. The steel structure can offer the highest material efficiency-less consumption of natural resources, less transport, fewer emissions, and energy consumption [3]. Steel has a very high capacity for recycling, which also results in the reduced consumption of natural resources and less waste, energy consumption, and emissions. 
The high quality and durability of steel constructions favor sustainable development. Cost, speed, quality, and market attractiveness are the main factors taken into account by investors and developers when deciding on the type of construction structure to be used. Both of them are worried about the budget, construction schedule, or market attractiveness of the facility, which should attract tenants and provide the investor with a fair profit over the entire life span of a building. Steel has a high potential for recycling, and most steel products used in building applications have a significant recycled content. Steel has long been the building material of choice for commercial construction for reasons of strength, durability, and stability. Although the LCA and embodied energy impacts associated with metals may appear to be higher than the alternatives, the inherent recyclability of metals and their durability and low maintenance make them competitive for high-performance building applications. Even while two out of every three pounds of new steel are produced from old steel, it is still necessary to continue to use some quantities of raw materials.

\section{New Construction Solutions}

In the long term, the strategy for sustainable development in the steel construction of office buildings assumes the development of steel structures which are more economical, technological, and friendlier to people and the environment. Steel recycling is the main advantage of its proecological image, but it should be remembered that good design plays a leading role, i.e., in preventing negative environmental impacts [4]. Currently, the applicable standards and design guidelines are aimed mainly at reducing material consumption and increasing the safety and quality of the structure. Solutions are promoted that allow the use of elements with a large span and also great versatility, enabling their reuse after dismantling the building. The extensive use of computeraided design (CAD/CAM) and the introduction of modern technologies in steel mills and steel structures factories have increased competition in the market, which is conducive to these phenomena. A new range of filling and insulating materials with better properties has also enabled the possibility of extremely high-comfort buildings while reducing the expenses associated with their operation or modernization.

New construction solutions mainly concern the internal partitions and curtain walls of building objects. Ceilings in multistory buildings are designed using steel beams and a reinforced concrete slab [5]. The floor slab usually consists of corrugated sheet metal, based on the upper or lower strips of the floor beam, and a concrete layer 130-150 mm thick. The span of floor beams, usually made of I-beams, is from 6 to $12 \mathrm{~m}$, although it can reach $18 \mathrm{~m}$. The width of the floor slab between the support beams ranges from 2.5 to $4.0 \mathrm{~m}$. Installation cables are placed in the ceiling space and can be suspended from the floor slab or with the help of special brackets attached to the floor beams. They can also pass through holes cut in the web of the beams. The integration of structural elements with internal installation pipes contributes to the reduction in ceiling thicknesses and thus the reduction in building height.

\section{Design for Deconstruction}

Reducing the demand for new material has a number of secondary environmental effects. The basis for designing a deconstruction is the concept of many layers of a building object with different service lives. This redefines the perception of buildings. Instead of perceiving them as a monolithic mass, the building is treated as a set of many interdependent layers interacting with each other during the exploitation phase [6]. According to this concept, buildings should be designed and built in such a way that components which require more frequent replacement or maintenance are not covered by long-term structural systems.

There are many principles to maximize the reuse of elements or recycling of materials in steel buildings. Among them, the most important are:

- using a standard column grid and interstory height;

- the connection of elements should facilitate dismantling; 
- using standard and reusable fixing should be considered (e.g., bolted connections instead of welded joints for steel structures);

- with regard to recycling after deconstruction, the use of structural systems that are easier to deconstruct and to demolish is recommended (elementary construction, steel vs. concrete);

- long beams to allow the flexibility of use;

- $\quad$ easy and permanent access to connection;

- $\quad$ avoiding corrosion of the steel members by constructive measures;

- avoiding paintings and fire protection spray or intumescent paints by fire engineering.

\section{Conclusions}

The use of steel as a construction material of office buildings, due to its minimal impact on the environment, is desirable to a much broader extent than before. Steel, as a product, meets many environmental criteria, among which the most important are the possibility of almost complete recycling, the minimum consumption of natural resources, the limited amount of waste, the possibility of reusing elements, and the ability to adapt the structure to the changing requirements of users. The energy consumption for the production and assembly of the steel structure represents only $3 \%$ of the total energy demand of the building throughout its lifespan.

Author Contributions: F.B. conceived and designed the analysis; F.B. and M.B. conducted the research; F.B. and M.B. wrote the paper.

Acknowledgments: This work was supported by the Polish Ministry of Science and Higher Education (research projects W/WB-IIŚ/12/2019 and WZ/WB-IIL/4 /2020).

Conflicts of Interests: The authors declare no conflict of interest.

\section{References}

1. Gültekın, H. Ecological design and retrieving the environmental meaning. In Memory in the Ontopoiesis of Life; Springer: Berlin, Germany, 2018; pp. 73-79.

2. Todd, J.; Brown. E.J.G.; Wells E. Ecological design applied. Ecol. Eng. 2003, 20, 421-440.

3. Brodka, J.; Broniewicz, M. Steel Structures from Hollow Sections; Arkady: Warsaw, Poland, 2001; p. 383. (In Polish)

4. Steel Construction. Commercial Buildings; The British Constructional Steelwork Association: London, UK, 2016.

5. Kanno, R. Advances in steel materials for innovative and elegant steel structures in Japan-A review. Struct. Eng. Int. 2016, 26, 242-253.

6. Chini, A.R.; Schultmann F. Deconstruction and Materials Reuse: Technology, Economic, and Policy. CIB Publication 266. In Proceedings of the CIB Task Group 39-Deconstruction Meeting, Karlsruhe, Germany, 9 April 2002; p. 244.

(C) 2020 by the authors. Licensee MDPI, Basel, Switzerland. This article is an open access article distributed under the terms and conditions of the Creative Commons Attribution (CC BY) license (http://creativecommons.org/licenses/by/4.0/). 